Кулакова Лариса

кандидат психологічних наук, доцент кафедри вікової та педагогічної психології Рівненського державного гуманітарного університету http://orcid.org/0000-0001-6496-7964

DOI https://doi.org/10.35619/praprv.v1i15.190

\title{
РОЗВИТОК СОЦАЛЬНОГО ІНТЕЛЕКТУ У ДІТЕЙ МОЛОДШОГО ШКІЛЬНОГО ВІКУ В УМОВАХ НАВЧАЛЬНОЇ ДІЯЛЬНОСТІ
}

\begin{abstract}
Анотація. Стаття присвячена актуальній проблемі сучасної освіти - соціально орієнтованій спрямованості освітньо-виховного прочесу. У публікації обтрунтовано наукову й практичну значущість проблеми розвитку сочіального сфери особистості. У статті розглядаються підходи до осмислення поняття соиіального інтелекту у иілому, наводяться певні точки зору вчених на природу соціального інтелекту, щуо пояснюють цуе соціальне явище як пристосування індивіда до сочіального буття. Визначено основні передумови для розвитку соиіального інтелекту у молодшому шкільному віці. 3'ясовано необхідність та можливості розвитку сочіального інтелекту у навчальній діяльності школярів. Розглядаються основні функиії сочіального інтелекту у молодшому шкільному віці (пізнавально-оцінна, комунікативно-ціннісна, рефлексивно-корекційна). Зроблено висновок про те, щуо розвиток соціального інтелекту є актуальною та затребуваною у сучасній освіті проблемою.
\end{abstract}

Ключові слова: інтелект, соціальний інтелект, молодший шкільний вік, молодші школярі, спілкування, міжособистісна взаємодія.

Постановка проблеми. Одне із пріоритетних завдань виховання підростаючого покоління на сучасному етапі - це навчити дитину свідомо орієнтуватися у соціумі та соціальних стосунках з іншими людьми. Щоб у майбутньому дитина стала затребуваним фахівцем та просоціальною особистістю, необхідно з дитинства розвивати у неї соціальний інтелект. І якщо ідеї розвитку інтелекту в цілому не $\epsilon$ новими, то багатьом аспектам розвитку саме соціального інтелекту сьогодні надається особлива увага. Актуальними залишаються питання взаємозв'язку соціального інтелекту із загальним розвитком дитини, iii психологічною культурою, його роллю в соціалізації особистості.

Соціальний інтелект є необхідним аспектом у розвитку дітей, адже міжособистісна взаємодія не буде успішною, якщо її учасники на вміють правильно розуміти свою поведінку та вчинки інших людей. Він $є$ важливою характеристикою особистості, яка визначає успішну взаємодію дитини з іншими людьми. Основна суть соціального інтелекту у тому, що людина здатна інтерпретувати і прогнозувати як поведінку партнера по спілкуванню, так і свою власну. Ця здатність до інтерпретації та передбачення дозволяє регулювати процес спілкування та міжособистісної атракції, робить їх більш продуктивними.

Проблема нашого дослідження знайшла своє відображення і у Законі України «Про освіту», де зазначається, що «освіта є основою інтелектуального, духовного ... розвитку особистості, іiі успішної соціалізації...» (2017). У Статті 3 Закону України «Про повну загальну середню освіту» чітко визначено, що «система загальної середньої освіти функціонує 3 метою забезпечення всебічного розвитку, навчання, виховання, виявлення обдарувань, соціалізації особистості, яка здатна до життя в суспільстві...» (2020). У зв'язку з цим виникає необхідність не тільки розвитку інтелектуальних здібностей школярів, але i формування у них навичок міжособистісної взаємодії.

Аналіз останніх досліджень 3 проблеми. На сьогодні не існує єдиного підходу щодо визначення поняття «соціальний інтелект». Також достеменно не сформована єдина наукова позиція щодо критеріїв, чинників, технологій вивчення й формування цієї значущої соціальної якості особистості на різних етапах іiї життя.

Однак, розуміючи наукову й практичну значущість проблеми розвитку соціальної сфери особистості, чимало науковців (Айзенк,.Богуш, Векслер, Гавриш, Гілфорд, Н.Кентор, 
Михайлова, Олпорт, Проценко, Савенков Селман, Стенберг, Торндайк та ін.) присвятили їй власні наукові розвідки.

Окремі аспекти, які стосуються визначення складових проблеми соціального інтелекту, вивчаються в контексті близьких за значенням понять: «комунікативна компетентність» (Андрєєва, Амінов, Коблянська, Петровська та ін.), «соціальна обдарованість» (Сиск, Уіддет), «комунікативний потенціал» (Рижов, Реан, Фельштейн та ін.), «соціальна компетентність» (Куніцина, Люсін, Проценко та ін.).

Мета статті: вивчити й теоретично обгрунтувати особливості розвитку соціального інтелекту у молодших школярів в умовах шкільного навчання.

Виклад основного матеріалу дослідження. Задля обгрунтування важливості та усієї сутності поняття «соціального інтелекту», розглянемо декілька основних та найбільш вживаних варіантів трактування його значення.

Термін «соціальний інтелект» першим ввів до психологічної науки Торндайк у 1920 році. Цим терміном він позначив «далекоглядність у міжособистісних стосунках». Як вважав Оллпорт (2002), соціальний інтелект - це особливий «соціальний дар», який забезпечує розуміння у відносинах 3 людьми, їх соціальне пристосування до навколишньої дійсності. Також вчений говорив і про те, що соціальний інтелект є певною особистісною властивістю, яка, разом з тим, не передбачає глибину розуміння об'єктів міжособистісної взаємодії (с. 253). За Куніциною (2002), соціальний інтелект - це глобальна здібність, що виникає на базі комплексів інтелектуальних, особистісних, комунікативних і поведінкових рис, включаючи рівень енергетичної забезпеченості процесів саморегуляції; ці риси обумовлюють прогнозування розвитку міжособистісних ситуацій, інтерпретацію інформації і поведінки, готовність до соціальної взаємодії.

Дослідження розвитку соціального інтелекту у зв'язку із віковим фактором у вітчизняній психології в більшості базується на основах вікової психології, закладених Виготським, Лєонтьєвим, Рубінштейном. Щоб розглянути та проаналізувати місце соціального інтелекту у структурі загального інтелекту, необхідно звернутися до класиків зарубіжної психології, а саме до робіт Г.Айзенка та Гілфорда.

Модель структури інтелекту за версією Айзенка представлена на рисунку 1.

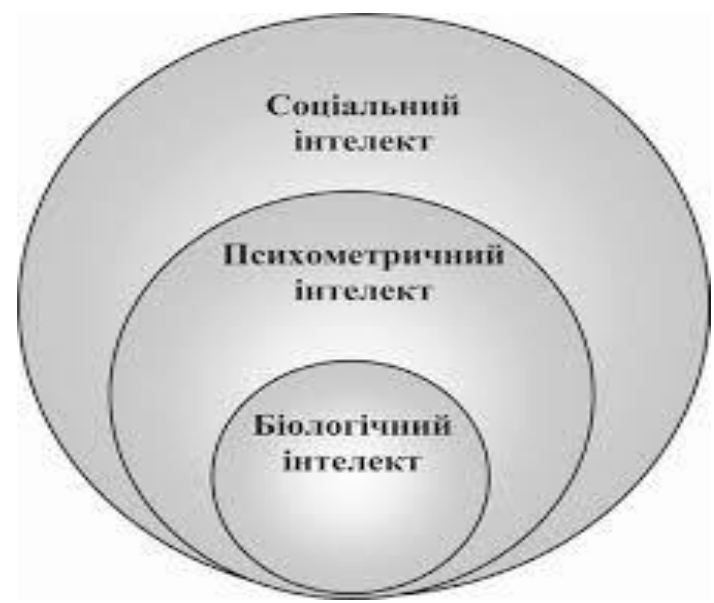

\section{Рис. 1. Взаємовключеність різних видів інтелекту за теорією Г. Айзенка}

Айзенк (1995) намагається протиставити різні види інтелекту один одному i, водночас, об'єднати їх, подати як єдине ціле. Вчений дає такі визначення видам інтелекту, які він розмістив у структурі загального інтелекту:

- біологічний інтелект - це вроджені здібності до обробки інформації, пов’язані із структурами і функціями кори головного мозку. Це фундаментальний вид інтелекту;

- психометричний інтелект - це свого роду сполучна ланка між біологічним та соціальним інтелектом. Деякі дослідники саме психометричний інтелект називають загальним; 
- соціальний інтелект - це інтелект індивіда, що формується в ході його соціалізації, під впливом умов соціального середовища (Интеллект: новый взгляд, 1995, с. 113).

Першим, хто створив надійний тест для вимірювання рівня соціального інтелекту, був Дж. Гілфорд (60-ті роки XX ст.). Вчений трактував соціальний інтелект як систему інтелектуальних здібностей, які є незалежними від загального фактора інтелекту і пов'язані, насамперед, 3 пізнанням поведінкової інформації. Дж. Гілфорд створив кубічну модель структури інтелекту, в якій виділено 120 факторів інтелекту, які класифікуються відповідно за трьома незалежними змінами, а саме: зміст пропонованої інформації; операції по обробці інформації; результати обробки інформації (Три стороны интеллекта, 1965, с. 8).

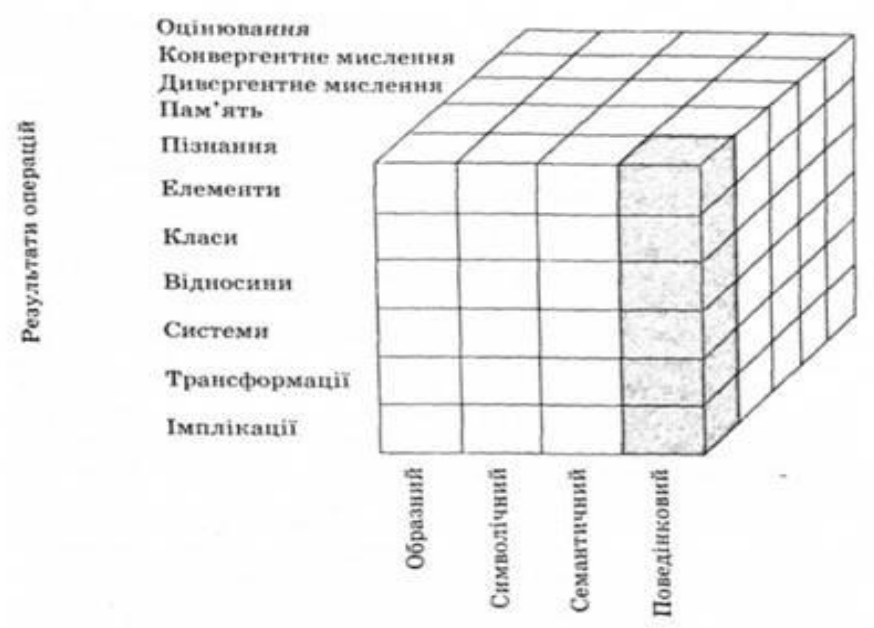

Рис. 2. Модель структури інтелекту за Дюс. Гілфордом (сірим кольором виділені параметри соціального інтелекту)

Усі дослідження соціального інтелекту Гілфорд (1965) звів до дослідження однієї операції - пізнання, а саме пізнання поведінки.

Пізнання включає в себе:

- пізнання елементів поведінки - здібність виділяти 3 контексту вербальну і невербальну експресію поведінки;

- пізнання класів поведінки - здібність розпізнавати загальні властивості у деякому потоці експресивної або ситуативної інформації про поведінку;

- пізнання відношень поведінки - здібність розуміти відношення, які існують між одиницями інформації про поведінку;

- пізнання системи поведінки - здібність розуміти логіку розвитку цілісних ситуацій взаємодії людей, сутність їх поведінки в цих ситуаціях;

- п пізнання перетворень поведінки - здібність розуміти зміни значень подібної поведінки (вербальної або невербальної) в різних ситуаціях, ситуаційних контекстах;

- пізнання результатів поведінки - здібність передбачення наслідків поведінки, виходячи з наявної інформації (Загальна психологія, 2005, с. 208).

- Вартою уваги є структура множинних інтелекті Гарднера, згідно якої можна виділити два види інтелекту, які безпосередньо пов'язані із соціальним:

- внутрішньо-особистісний інтелект - здатність звертатися до власних внутрішніх психічних процесів, розуміти себе, свої цілі, емоції;

- міжособистісний інтелект - здатність розуміти почуття, наміри інших (Структура разума, 2007, с. 227).

На сучасному етапі розвитку психологічної науки провідним напрямком дослідження соціального інтелекту як основного механізму успішної комунікативної діяльності особистості у суспільстві, вважаються роботи Стернберга. Соціальний інтелект, згідно інтерпретації вченого, включає в себе: здатність до вирішення практичних завдань 
(отримання інформації, ефективна комунікація, прийняття адекватних рішень); володіння вербальними здібностями (широкий лексикон, результативне спілкування 3 людьми, відсутність труднощів у сприйнятті інформації у будь-якому вигляді); соціальна компетентність (Практический интеллект, 2002, с. 227).

Аналіз наукових розвідок В. Н. Куніциної (2002) дав змогу виділити структура суто соціального інтелекту. До неї відносять:

- комунікативно особистісний потенціал. Даний компонент представляє собою комплекс психічних властивостей, що полегшують або ускладнюють спілкування, на основі якого формуються такі інтегральні комунікативні властивості, як психологічна контактність та комунікативна сумісність;

- самосвідомість, характеристиками якої виступають відчуття самоповаги, відсутність комплексів, особливості Я-образу та Я-концепції;

- соціальна перцепція як здібність до розуміння людей i їх мотивів; вміння прогнозувати розвиток міжособистісних ситуацій (Уровни развития основных компонентов социального интеллекта младших подростков, 2011, с.89).

На нашу думку, найбільш повною постає модель соціального інтелекту, описана в концепції Савенкова (2006). Автор виділяє два фактори соціального інтелекту:

- декларативні кристалізовані соціальні знання (знання, отримані в результаті соціального научіння) та дослідні знання (отримані в результаті власної соціальноекспериментальної практики);

- - - -оціально-когнітивну гнучкість - здатність застосовувати соціальні знання при вирішенні нових проблем.

Узагальнюючи уже існуючі теорії, вчений характеризує три групи здібностей, які визначають соціальний інтелект: пізнавальні, емоційні і поведінкові. Як вважає Савенков, кожну із цих груп можна представити таким чином:

\section{1. Пізнавальні здібності:} людей);

- соціальні знання (знання про людей, знання спеціальних правил, розуміння інших

- соціальна пам'ять - пам'ять на імена, особи;

- соціальна інтуїція (оцінка почуттів, визначення настрою, розуміння мотивів вчинків інших людей, здатність адекватно сприймати поведінку в рамках соціального контексту);

- соціальне прогнозування (планування власних дій, відстеження свого розвитку, його рефлексія і оцінка невикористаних альтернативних можливостей).

2. Емоиійні здібності:

- експресивна виразність (емоційна виразність, емоційна чутливість, емоційний контроль);

- співпереживання (здатність вчуватися в інших людей, ставити себе на їх місце);

- здатність до саморегуляції (вміння регулювати власні емоції і настрій).

3. Поведінкові здібності:

- соціальне сприйняття (уміння слухати й розуміти співрозмовника);

- соціальна взаємодія (здатність і готовність співпрацювати, спроможність до колективної взаємодії і колективної творчості);

- соціальна адаптація (вміння пояснювати і переконувати інших, здатність уживатися з іншими людьми, відкритість у стосунках з соціальним оточенням) (Концепщия социального интеллекта, 2006, с.14).

Кожен віковий період характеризується інтенсивним розвитком не лише інтелектуальних здібностей особистості, а й міжособистісної взаємодії, уявлень і навичок ефективної соціальної поведінки. Соціальний інтелект, як показують дослідження вітчизняних та зарубіжних вчених, $є$ інтегральною здібністю, що в процесі онтогенезу має 
тенденцію до зміни свого рівня.

Так, у молодшому шкільному віці розвиток соціального інтелекту набуває особливої значущості. На рубежі дошкільного та молодшого шкільного віку відбувається зміна соціальної ситуації розвитку, яка відображає специфіку взаємовідносин дитини із найближчим соціальним оточенням. Соціальна ситуація розвитку у молодшому шкільному віці - це ситуація навчання. Відповідно, провідним видом діяльності є навчальна діяльність.

Психологічні новоутворення, що виникають і розвиваються у молодших школярів у процесі формування навчальної діяльності, характеризуються важливими досягненнями в розвитку молодших школярів і стають фундаментом, який забезпечує особистісний розвиток на наступному віковому етапі.

У молодшому шкільному віці дитина починає керуватися у своїй поведінці моральними нормами. Діти, оцінюючи свою поведінку та вчинки інших людей, керуються певними морально-етичними уявленнями. У них починають формуватися стійкі моральні уявлення, а також здатність до моральної саморегуляції. Джерелом моральних уявлень дітей $\epsilon$ дорослі, які навчають та виховують дитину, а також однолітки. Моральний досвід від дорослих до дітей передається та засвоюється у процесі спілкування, спостереження та наслідування, через систему заохочень та покарань. Ситуація сучасного шкільного навчання вимагає від дитини активного вирішення нових складних соціальних задач.

У цей період відбувається перебудова всієї системи стосунків дитини з дійсністю. Зміна соиіальної ситуащії розвитку полягає у виході дитини за рамки сім'ї, в розширенні кола значущих осіб, у виділенні особливого типу стосунків з дорослим, опосередкованих задачею («дитина - дорослий - задача»). Центром життя молодшого школяра стає система «дитина учитель», яка визначає ставлення дитини до батьків і однолітків (Павелків, 2011, с. 183).

Для того, щоб пристосуватися до умов навчання i в подальшому зберігати адаптованість до шкільного життя, успішно взаємодіяти з педагогами та однолітками, стати частиною колективу і заявити в ньому про себе, дитині необхідні певні соціальні навички. Соціальні навички відображають вимоги і норми, що існують в тому освітньому середовищі, де перебуває дитина. Чим успішніше дитина справляється із соціальним аспектом ролі учня в молодшому шкільному віці, тим імовірнішим $\epsilon$ той факт, що іiі соціальний інтелект розвинений на досить високому рівні. Період навчання в початковій школі розглядається психологами як один з найскладніших періодів дитинства, оскільки в цей час закладаються основи розвитку на наступних вікових етапах, що припадають на шкільні роки. Тут мають значення не тільки загальна тенденція академічної успішності, але i характеристики емоційної і соціальної сфер, що становлять фундамент особистісного розвитку.

Ми можемо стверджувати, що соціальний інтелект дітей молодшого шкільного віку виконує такі основні функції: пізнавально-оцінну; комунікативно-ціннісну; рефлексивнокорекційну.

Перша функція полягає у визначенні індивідуальних можливостей дитини задля досягнення результатів діяльності, надання допомоги іншим людям, у визначенні змісту міжособистісної взаємодії з однолітками та дорослими. Завдяки такій функції відбувається усвідомлення інформації, необхідної для передбачення результатів діяльності.

Комунікація забезпечує дітям отримання достовірної інформації про соціум і здійснення зворотного зв'язку у вигляді ціннісних уявлень про нього. За рахунок ціннісного компоненту комунікативно-ціннісної функції формується ставлення до оточуючої дійсності та до того, що в ній відбувається.

Рефлексивно-корекційна функція соціального інтелекту дітей молодшого шкільного віку проявляється в усвідомленні того, як вони сприймаються іншими. Ця функція надає можливість коригувати взаємодію 3 соціальним середовищем і сприяє встановленню рівноваги між інтелектуальною та емоційною сферами особистості. Зазначені функції соціального інтелекту молодших школярів $є$ взаємообумовленими і взаємозалежними.

Висновки і перспективи подальших розвідок. Отож, соціальний інтелект - це здатність адекватно розуміти та інтерпретувати поведінку людей. Ця здатність необхідна для ефективної міжособистісної взаємодії, а також успішної соціальної адаптації дитини 
молодшого шкільного віку. Формування особистості дітей молодшого шкільного віку відбувається в умовах взаємодії з освітнім середовищем, яке здійснює на них вплив i, безумовно, виховує. В процесі життя і діяльності в колективі відбувається перебудова всієї системи взаємин молодших школярів 3 дійсністю. Система «дитина - дорослий» диференціюється; система «дитина - вчитель» починає визначати ставлення дитини до батьків і ставлення дитини до однолітків. Відбувається постійний взаємовплив учнів один на одного, під час якого формуються оцінка та самооцінка, погляди на події навколишнього життя, розвивається соціальна компетентність дітей.

\section{СПИСОК ПОСИЛАНЬ}

Айзенк, Г. Ю. Интеллект: новый взгляд. Вопросы психологи, 1, 111-131.

Гарднер, Г. (2007). Структура разума: теория множественного интеллекта. Москва: ООО «И. Д. Вильяме».

Гилфорд, Дж. (1965). Три стороны интеллекта. Москва: Прогресс.

Козляковський, П. А. (2005). Загальна психологія: Підручник. Миколаїв: Дизайн і поліграфія. Куницына, В. Н. (2002). Межличностное общение: Учебник для вузов. Санкт-Петербург: Питер.

Оллпорт, Г. (2002). Становление личности: Избранные труды. Москва: Смысл.

Павелків, Р. (2001). Вікова психологія. Київ: Кондор.

Панова, Н. В. (2011). Уровни развития основных компонентов социального интеллекта младших подростков. Интеграџия образования. 2, 88-92.

Про освіту : Закон України. (2017). Відомості Верховної Ради (ВВР), 38-39, 380.

Про повну загальну середню освіту : Закон України. (2020). Відомості Верховної Ради (ВВР), $31,226$.

Савенков, А. (2006). Концепция социального интеллекта. Одаренный ребенок, 1, 6-18.

Стенберг, Дж. (2002). Практический интеллект. Санкт-Петербург: Питер.

\section{REFERENCES}

Ayzenk, G.Yu. Intellekt: novyy vzglyad [Intelligence: a new look]. Voprosy psikhologii. 1. 111131. [in Russian].

Gardner, G. (2007). Struktura razuma: teoriya mnozhestvennogo intellekta [The structure of mind: theory of multiple intelligences]. Moskva: OOO «I. D. Viliame». [in Russian].

Gilford, Dzh. (1965). Tri storony intellekta [Three sides of intelligence]. Moskva: Progress.

[in Russian].

Kozliakovskyi, P. A. (2005). Zahalna psykholohiia: Pidruchnyk [General psychology: Textbook]. Mykolaiv: Dyzain i polihrafiia. [in Ukrainian].

Kunitsyna, V. N. (2002). Mezhlichnostnoye obshcheniye: uchebnik dlya vuzov [Interpersonal Communication: A textbook for high schools]. Sankt-Peterbug: Piter. [in Russian].

Ollport, G. (2002). Stanovleniye lichnosti: Izbrannyye trudy [Personal formation: Selected works]. Moskva: Smysl. [in Russian].

Pavelkiv, R. (2001). Vikova psykholohiia [Age psychology]. Kyiv: Kondor. [in Ukrainian].

Panova, N. V. (2011). Urovni razvitiya osnovnykh komponentov sotsialnogo intellekta mladshikh podrostkov [Development levels of the main components of social intelligence in younger adolescents]. Integratsiya obrazovaniya, 2. 88-92. [in Russian].

Pro osvitu : Zakon Ukrainy [About education : Law of Ukraine]. (2017). Vidomosti Verkhovnoi Rady (VVR), 38-39, 380. [in Ukrainian].

Pro povnu zahalnu seredniu osvitu : Zakon Ukrainy [On complete general secondary education: Law of Ukraine]. (2020). Vidomosti Verkhovnoi Rady (VVR), 31, 226. [in Ukrainian].

Savenkov, A. (2006). Kontseptsiya sotsialnogo intellekta [Social intelligence concept]. Odarennyy rebenok. 1. 6-18. [in Russian].

Stenberg, Dzh. (2002). Prakticheskiy intellect [Practical intelligence]. Sankt-Peterburg: Piter. [in Russian]. 


\title{
DEVELOPMENT OF SOCIAL INTELLIGENCE IN CHILDREN OF PRIMARY SCHOOL AGE IN THE CONDITIONS OF LEARNING ACTIVITY
}

\author{
Candidate of Psychological Sciences, Associate Professor of \\ Department of Lifespan \& Pedagogical Psychology \\ http://orcid.org/0000-0001-6496-7964 \\ DOI https://doi.org/10.35619/praprv.v1i15.190
}

\begin{abstract}
The article is devoted to the actual problem of modern education - socially oriented focus of the educational process. The publication substantiates the scientific and practical significance of the problem of development of the social sphere of the individual. The article examines approaches to understanding the concept of social intelligence in general, are given some scientists point of view on the nature of social intelligence which explain this social phenomenon as the adaptation of the individual to social life. In particular, the analysis of the structure of intelligence by H. Eysenck, J. Guildford, R. Sternberg, A. Savenkov, N. Kunitsyna was carried out. The article analyses the psychological features of primary school age as a sensitive period of ontogenesis for the development of social intelligence. The main prerequisites for the development of social intelligence in primary school age are identified. The necessity and possibilities of development of social intelligence in educational activity of schoolchildren are found out. The main functions of social intelligence in primary school age are examined (cognitive-evaluative, communicative-value, corrective - reflexive). It was concluded that the development of social intelligence is an urgent and submitted problem in modern education.
\end{abstract}

Key words: intelligence, social intelligence, primary school age, younger schoolchildren, communication, interpersonal interaction. 